\title{
Produksi Kacang Tunggak (Vigna unguiculata [L.] Walp) dengan Input Pupuk Rendah
}

\section{Production of Cowpea (Vigna unguiculata [L.] Walp) with Low Input of Fertilizer}

\author{
Resti Fadillah $^{1}$, Heni Purnamawati ${ }^{*}$, dan Supijatno ${ }^{2}$ \\ ${ }^{1}$ Program Studi Agronomi dan Hortikultura, Sekolah Pascasarjana, Institut Pertanian Bogor \\ ${ }^{2}$ Departemen Agronomi dan Hortikultura, Fakultas Pertanian, Institut Pertanian Bogor \\ (Bogor Agricultural University), Jl. Meranti, Kampus IPB Darmaga, Bogor 16680, Indonesia
}

Diterima 19 September 2019/Disetujui 17 April 2020

\begin{abstract}
Cowpea is prospective as a substitute for soybeans, as raw material for tempeh. In this study, low inputs of cowpea production is proposed. This study aimed to determine the effect of manure and nitrogen fertilizer on the growth and production of cowpea. The study was conducted at the Cikabayan Experimental Station, IPB, Bogor, Indonesia, from November 2018 to March 2019, using a split-plot design. As the main plot was goat manure rates consisted of 0, 2.5, and 5 tons ha ${ }^{-1}$. The subplots consisted of four rates of nitrogen, namely $0,15,30$, and $45 \mathrm{~kg} \mathrm{~N} \mathrm{ha}^{-1}$. The results showed that the application of manure increased the fresh weight of the leaf, the number of flower bunches, and the number of flowers. The application of $N$ fertilizer increased leaf fresh weight, leaf area index, dry root weight, and shoot/root ratio at five weeks after planting. The combination of organic fertilizer with a dose of 2.5 tons ha $\mathrm{h}^{-1}$ combined with $45 \mathrm{~kg} \mathrm{ha}^{-1}$ nitrogen fertilizer tends to give better productivity than without fertilizer. Thus, cowpea can be produced using low input of manure and $N$.
\end{abstract}

Keywords: leaf area index, leaf weight, flower bunches

\section{ABSTRAK}

Kacang tunggak memiliki prospek sebagai pengganti kedelai, sebagai bahan baku tempe. Perlu dikaji pemupukan dosis rendah pada produksi kacang tunggak. Penelitian ini bertujuan untuk mengetahui pengaruh aplikasi pupuk kandang dan Nitrogen terhadap pertumbuhan dan produksi tanaman kacang tunggak. Penelitian dilakukan di Kebun Percobaan Cikabayan, Institut Pertanian Bogor, pada bulan Novemeber 2018-Maret 2019, dengan menggunakan rancangan split plot. Petak utama aplikasi pupuk kandang kambing terdiri dari tiga taraf yaitu 0, 2.5, dan 5 ton ha'. . Anak petak terdiri atas empat taraf yaitu 0, 15, 30, dan $45 \mathrm{~kg}$ pupuk $N \mathrm{ha}^{-1}$. Hasil penelitian menunjukkan pemberian pupuk kandang meningkatkan bobot segar daun, jumlah tandan bunga, pada 5 minggu setelah tanam (MST). Pemberian nitrogen meningkatkan bobot segar daun, indeks luas daun, bobot segar akar dan jumlah bunga pada 5 MST. Kombinasi pemberian pupuk organik dengan dosis 2.5 ton ha ${ }^{-1}$ dan pupuk nitrogen $45 \mathrm{~kg} \mathrm{ha}^{-1}$ memberikan pertumbuhan dan produksi yang cenderung lebih baik daripada tanpa pemupukan. Dengan demikian kacang tunggak dapat diproduksi dengan input pupuk kandang dan $N$ yang rendah.

Kata kunci: bobot segar daun, indeks luas daun, tandan bunga

\section{PENDAHULUAN}

Tanaman kacang tunggak (Vigna unguiculata L.Walp) termasuk keluarga Leguminoceae. Tanaman yang diperkirakan berasal dari Afrika Barat ini tersebar di beberapa daerah tropik dan subtropik. Potensi hasil kacang tunggak yang toleran terhadap lahan masam memiliki potensi hasil biji 1,000-1,200 $\mathrm{kg} \mathrm{ha}^{-1}$ (Setyowati dan Sutoro, 2010).

\footnotetext{
* Penulis untuk korespondensi. e-mail: henipurnamawati1@gmail. com
}

Kacang tunggak dapat dimanfaatkan sebagai tanaman bahan pangan dan pakan. Daun kacang tunggak merupakan sayuran fungsional yang bergizi sehingga dapat dikonsumsi (Enyiukwu et al., 2018). Kritzinger et al. (2015) menunjukkan hasil ekstrak kacang tunggak dapat menghambat pertumbuhan bakteri dan jamur patogen. Potensi hasil biji kacang tunggak cukup tinggi, dapat sebagai bahan tempe kacang tunggak dan cookies berprotein (Wardiah et al., 2016; Murtini dan Lestari, 2017). Kacang tunggak mengandung protein 22-30\%, karbohidrat 3359.59\%, kadar abu 3.60-4.21\%, dan serat kasar 2.10-2.98\% (Carvalho, 2012; Animasaun et al., 2015). Tempe kacang tunggak memiliki kandungan lemak $0.67 \%$ dan aktivitas 
antioksidan $59.6 \%$ lebih tinggi dibanding tempe kedelai dengan kandungan lemak $8.20 \%$ dan aktivitas antioksidan 56.66\% (Dewi et al., 2008).

Upaya untuk memperoleh pertumbuhan dan produksi yang tinggi pada kacang tunggak, adalah dengan perbaikan budidaya, salah satunya dengan aplikasi pupuk organik dan anorganik. Pupuk kandang yang merupakan pupuk organik dari limbah hewan peliharaan dapat digunakan untuk menambah hara, memperbaiki sifat fisik dan biologi tanah, sehingga dapat meningkatkan produksi polong kacang tanah (Mukhtar et al., 2014). Pemberian pupuk kandang ayam berperan pada perbaikan perubahan sifat fisik tanah terutama agregat tanah, kadar air kapasitas lapang dan porositas (Ramli et al., 2016). Kacang tunggak dapat terinokulasi bakteri yang memfiksasi nitrogen. Bintil akar dapat secara efisien memberikan $\mathrm{N}$ pada tanaman saat umur 21-28 hari setelah tanam (Suryantini, 2015; Hindersyah et al., 2017). Pemberian pupuk nitrogen dibutuhkan untuk pertumbuhan tanaman hingga bintil akar dapat memberikan $\mathrm{N}$ pada tanaman (Boroomandan et al., 2009). Namun, Liana et al. (2019) mendapatkan bahwa, dengan pemberian pupuk nitrogen hingga dosis $90 \mathrm{~kg} \mathrm{~N}^{-1}$ dan pupuk kandang kambing 5 ton ha-1 menurunkan produksi biji kering hingga $30 \%$ pada tanaman kacang tunggak, oleh karena itu perlu dipelajari apakah kacang tunggak dapat ditingkatkan produksinya dengan input pupuk rendah.

\section{BAHAN DAN METODE}

Bahan tanam yang digunakan adalah benih lokal (landrace) kacang tunggak dengan warna biji putih, hilum berwarna hitam (black eyed pea) dan telah adaptif pada lingkungan lahan masam. Pupuk yang digunakan adalah pupuk kandang kambing, sedangkan urea digunakan sebagai pupuk starter. Bahan lain yang digunakan adalah insektisida dengan bahan aktif Deltametrin $25 \mathrm{~g} \mathrm{~L}^{-1}$.

Penelitian ini dilakukan di Kebun Percobaan Cikabayan, Institut Pertanian Bogor, mulai bulan Novemeber 2018 sampai dengan Maret 2019. Percobaan ini menggunakan rancangan split plot dengan tiga ulangan. Petak utama adalah dosis pupuk kandang kambing terdiri atas tiga dosis yaitu $0,2.5$, dan 5.0 ton $\mathrm{ha}^{-1}$. Anak petak adalah pemberian pupuk nitrogen $(\mathrm{N})$ terdiri atas empat dosis yaitu $0,15,30$, dan $45 \mathrm{~kg} \mathrm{~N}^{-1}$ yang berfungsi sebagai starter. Sumber pupuk nitrogen adalah pupuk urea $46 \% \mathrm{~N}$. Setiap perlakuan ditanam pada satu petak dengan ukuran $2.4 \mathrm{~m} \times 1 \mathrm{~m}$. Jarak tanam yang digunakan adalah $60 \mathrm{~cm} \times 40$ $\mathrm{cm}, 1$ tanaman per lubang. Kacang tunggak yang ditanam merupakan tipe indeterminat sehingga jika ditanam dengan jarak rapat daun tanaman akan saling menutupi. Jarak tanam anjuran pada pertanaman kacang tunggak menurut Balitkabi (1998) adalah $40 \mathrm{~cm} \times 10 \mathrm{~cm}, 1$ tanaman per lubang pada tipe kacang tunggak tegak.

Pupuk kandang diberikan dua minggu sebelum tanam dengan cara disebar dalam larikan dangkal sejauh $\pm 10 \mathrm{~cm}$ dari lubang tanam. Penanaman dilakukan dengan cara ditugal dan di setiap lubang tanam diberi insektisida berbahan aktif karbofuran dengan dosis $10 \mathrm{~kg} \mathrm{ha}^{-1}$. Pupuk nitrogen diberikan pada umur 5 hari setelah tanam dengan cara dilarik sekitar $5 \mathrm{~cm}$ dari lubang tanam.

Pemasangan ajir dilakukan pada 3 minggu setelah tanam (MST). Panen dilakukan setelah kulit polong berubah warna dari hijau menjadi coklat (Trustinah 1998), mulai mengering, dan panen dilakukan bertahap pada umur 59, 65, 71, 77, dan 81 hari setelah tanam (HST).

Pengamatan yang dilakukan dalam penelitian ini meliputi analisis kimia tanah awal dan akhir, analisis kimia pupuk kandang di Laboratorium Pengujian Departemen Agronomi dan Hortikultura IPB, curah hujan, waktu berbunga, jumlah bunga, dan tandan bunga, luas daun, indeks luas daun, bobot daun tanaman, bobot 100 biji dan bobot biji tiap petak percobaan pada kandungan air 13\%. Destruktif sampel dilakukan untuk pengamatan bobot segar daun, indeks luas daun, bobot akar, jumlah tandan bunga, dan jumlah bunga pada 50\% tanaman berbunga. Destruktif dilakukan pada dua tanaman per perlakuan pada umur 5 MST. Data yang di peroleh dianalisis menggunakan sidik ragam; apabila berpengaruh nyata akan dilanjutkan dengan uji BNJ taraf 5\%. Data dianalisis menggunakan software SAS 9.4 .

\section{HASIL DAN PEMBAHASAN}

Analisis kimia tanah awal menunjukkan tingkat kemasaman $(\mathrm{pH})$ tanah pada penelitian ini bernilai sangat masam (4.15), C-organik 1.63\%, N total rendah (0.06\%), Ptersedia sangat rendah $(1.81 \mathrm{ppm}), \mathrm{K}$-tersedia sangat tinggi (91.8 ppm), dan KTK tanah sangat tinggi (53.38 $\mathrm{cmol}^{(+)}$ $\mathrm{kg}^{-1}$ ). Rata-rata curah hujan bulanan saat penelitian bulan November 2018 sampai Maret 2019 yaitu $296.96 \mathrm{~mm}$.

Perlakuan pupuk kandang dan pupuk nitrogen tidak mempengaruhi waktu $50 \%$ tanaman berbunga. Tanaman berbunga berkisar pada umur 40-41 HST. Hasil penelitian menunjukkan adanya pengaruh interaksi antara pupuk kandang dan pupuk nitrogen pada tiga peubah vegetatif yaitu bobot segar daun, bobot akar, dan indeks luas daun, dan dua peubah generatif tanaman yaitu jumlah tandan dan jumlah bunga (Gambar 1). Tanaman kacang tunggak yang mendapat perlakuan pupuk kandang 5 ton ha' ${ }^{-1}$ dan $45 \mathrm{~kg} \mathrm{~N}$ $\mathrm{ha}^{-1}$ secara nyata memberikan hasil tertinggi untuk kelima peubah tersebut (Gambar 1).

Pupuk kandang merupakan salah satu pupuk organik, yang dapat mendorong perkembangan akar (Atmaja et al., 2017), dapat meningkatkan kemampuan tanah untuk memegang air dan menyediakan hara untuk pertumbuhan tanaman. Hal ini di dukung oleh pendapat Uwah dan Eyo (2014) bahwa pupuk kandang dapat meningkatkan pH, kandungan bahan organik, $\mathrm{N}$ total, $\mathrm{P}$ tersedia, pertukaran $\mathrm{K}$, $\mathrm{Ca}, \mathrm{Mg}$ dan kapasitas tukar kation tanah. Pada penelitian ini pupuk kandang yang digunakan mengandung nitrogen $1.13 \%$, fosfor $0.79 \%$, dan kalium $2.49 \%$, sehingga tanaman mendapat tambahan hara $\pm 17.3-34.5 \mathrm{~kg} \mathrm{~N} \mathrm{ha}^{-1}, 12.1-24.1$ $\mathrm{kg} \mathrm{P}_{2} \mathrm{O}_{5}$ ha $^{-1}$, 38.0-76.0 $\mathrm{kg} \mathrm{K}_{2} \mathrm{O}^{-3} \mathrm{ha}^{-1}$ dari pupuk kandang.

Dosis pupuk kandang 5 ton ha- ${ }^{-1}$ dikuti $45 \mathrm{~kg} \mathrm{~N}^{-1}$ menghasilkan rata-rata bobot segar daun dan indeks luas daun pada umur 5 MST yang tertinggi (Gambar 1A). 
Dengan ketersediaan hara yang cukup terutama penambahan pupuk kandang, dapat meningkatkan pertumbuhan dan perkembangan tanaman (Diniarini et al., 2014). Hasil penelitian Hayati (2010); Rastiyanto et al. (2013) menunjukkan pupuk kandang berpengaruh nyata dalam meningkatkan bobot segar tanaman selada dan kailan. Bobot segar daun merupakan hasil aktifitas metabolisme, akumulasi fotosintat dalam bentuk biomas selama masa pertumbuhan, yang dapat ditandai dengan pertambahan bobot. Bobot segar daun mampu mencerminkan fungsi fisiologis daun terkait dengan fotosintesis dan respirasi (Huang et al., 2019).

Pemberian pupuk kandang pada tanaman kacang tunggak meningkatkan jumlah tandan bunga dan jumlah bunga per tanaman, dan makin tinggi penambahan dosis pupuk $\mathrm{N}$ semakin banyak bunga yang dihasilkan tanaman (Gambar 1). Peningkatan jumlah bunga berbanding lurus dengan peningkatan tandan bunga dengan persamaan regresi $\mathrm{Y}=0.8432 \mathrm{x}+3.4326$ nilai $\mathrm{R}^{2}=1$ (Gambar 2$)$. Peningkatan jumlah bunga dipengaruhi oleh suplai nitrogen pada tanaman, peningkatan suplai $\mathrm{N}$ meningkatkan pertumbuhan dan hasil tanaman bunga matahari dan safflower (Abbadi et al., 2008). Pupuk kandang memperbaiki kondisi tanah sehingga menciptakan lingkungan tumbuh yang sesuai bagi pertumbuhan dan dapat meningkatkan serapan P (Siregar et al., 2015). Unsur $\mathrm{P}$ berperan dalam pembelahan sel baru pada jaringan tanaman yang sedang tumbuh seperti pertambahan tinggi, jumlah cabang dan jumlah daun(Liferdi, 2010). Unsur K berperan sebagai pengatur membuka dan menutupnya stomata (Prajapati dan Modi, 2012). Peran stomata sangat penting untuk proses fotosintesis, transportasi air dan pendinginan tanaman. Ketika $\mathrm{K}^{+}$bergerak ke dalam sel-sel pelindung di sekitar stomata, sel-sel menumpuk air dan membengkak, menyebabkan stomata terbuka dan memungkinkan gas $\mathrm{CO}_{2}$ bergerak bebas masuk dan keluar. Ketika pasokan air sedikit, $\mathrm{K}^{+}$keluar dari sel penjaga stomata menutup rapat untuk mencegah hilangnya air dan meminimalkan stres kekeringan pada tanaman (Thomas dan Thomas, 2009).

Hasil pengamatan menunjukkan bahwa pemberian pupuk nitrogen mempengaruhi bobot segar daun, indeks luas daun (ILD), bobot kering akar dan jumlah bunga pada umur 5 MST. Pada fase vegetatif unsur hara terutama nitrogen dibutuhkan lebih banyak, semakin banyak hara yang diserap maka bobot segar daun, ILD dan bobot tajuk akan semakin tinggi (Tabel 1). Pemberian pupuk nitrogen bertujuan untuk menyediakan nutrisi diawal pertumbuhan tanaman agar fotosintesis berjalan optimal sebelum simbiosis efektif bekerja. Tanaman kacang tunggak pada 5 MST tampaknya mampu bersimbiosis dengan bakteri rhizobium untuk memenuhi kebutuhan nitrogen, ditandai dengan warna bintil akar yang berwarna merah muda (Gambar 3). Suryantini (2015) menyatakan bahwa bintil akar secara efisien dapat memberikan $\mathrm{N}$ untuk tanaman kacang tanah pada kisaran umur 21-28 hari setelah tanam.

Indeks luas daun merupakan perbandingan luas daun total dengan luas tanah yang ditutupi atau luas daun diatas luasan tanah. Peningkatan taraf dosis nitrogen hingga $45 \mathrm{~kg}$
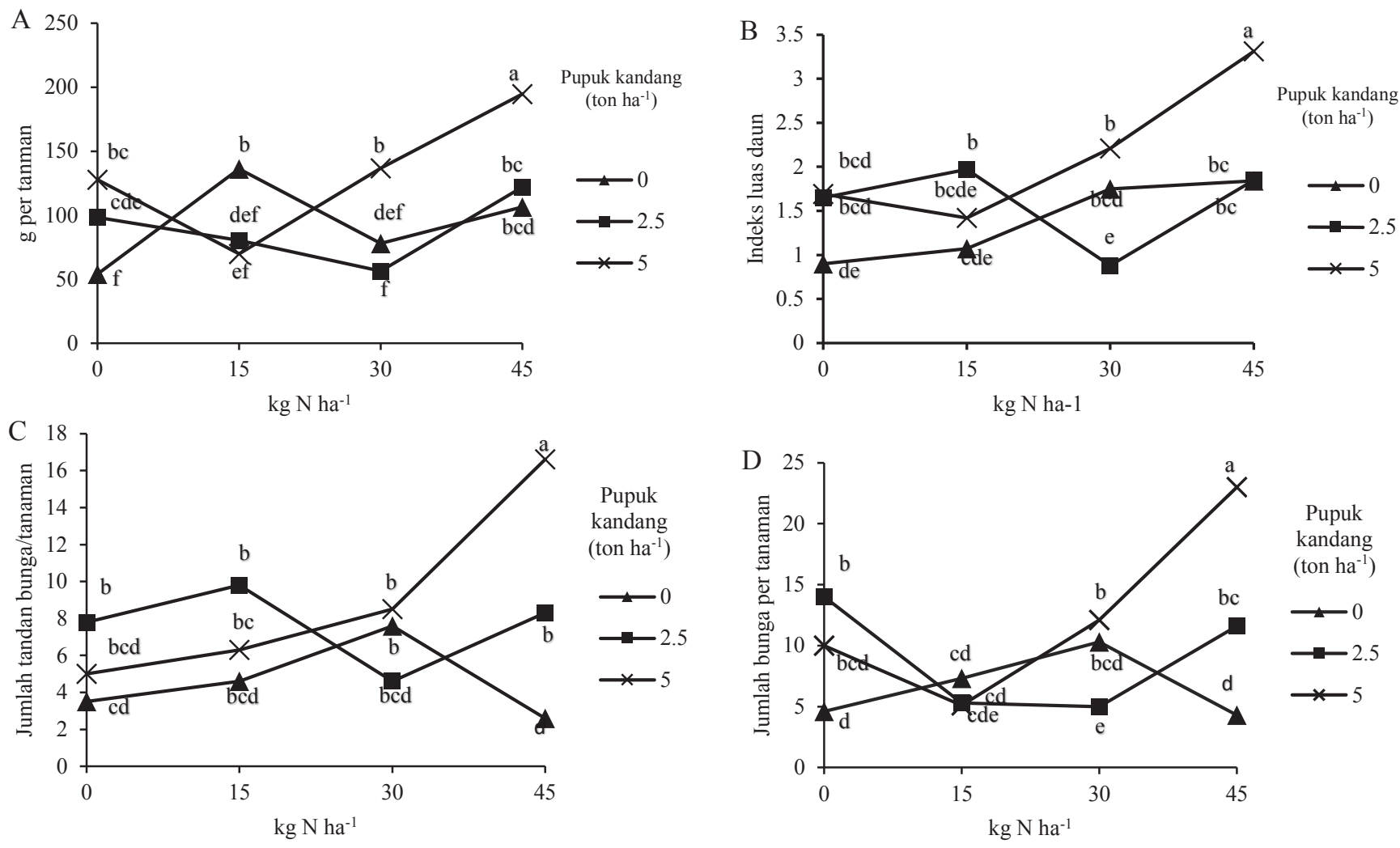

Gambar 1. Interaksi pupuk kandang dan pupuk nitrogen terhadap (A) bobot segar daun, (B) Indeks luas daun, (C) Jumlah tandan bunga per tanaman, (D) jumlah bunga per tanaman; huruf yang sama menunjukan tidak berbeda nyata menurut uji BNJ taraf 5\% 


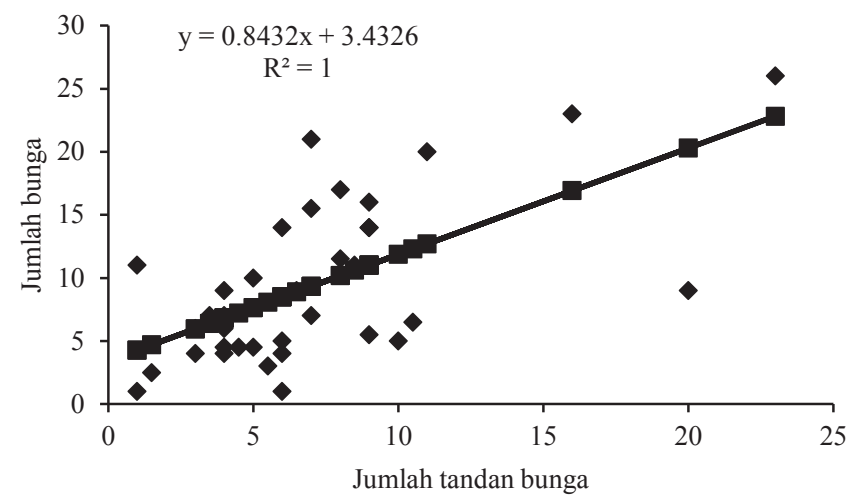

Gambar 2. Regresi jumlah tandan bunga (x) dan jumlah bunga (y)

$\mathrm{N}^{-1}$ nyata meningkatkan ILD tanaman $5 \mathrm{MST}$. Penelitian lain menunjukkan bahwa pembatasan hara nitrogen mempengaruhi ILD tanaman kentang serta juga dipengaruhi oleh faktor genotip (Horvath et al., 2014). Cahaya yang masuk melalui kanopi akan mempengaruhi pembentukan bunga, kondisi optimal iklim mikro, dan berpengaruh terhadap fisiologi tanaman (Zakariyya, 2016). Peningkatan dosis nitrogen menghasilkan tanaman dengan tajuk yang lebih besar, ditandai dengan nilai ILD dan rasio tajuk/ akar yang tinggi (Tabel 1). Tajuk yang besar kadang tidak menguntungkan karena mengurangi intersepsi cahaya yang diterima oleh tanaman sehingga hasil fotosintesis bersih berkurang dengan banyaknya daun-daun yang ternaungi (Purnamawati et al., 2010).

Nitrogen yang diberikan hingga $45 \mathrm{~kg} \mathrm{~N}^{-1}$ dapat meningkatkan vegetatif tanaman, tetapi belum mampu meningkatkan produksi biji (Tabel 1 dan Tabel 2). Liana et al. (2019) menunjukkan cenderung terjadi penurunan bobot biji kering kacang tunggak per $\mathrm{m}^{2}$ pada peningkatan dosis aplikasi $\mathrm{N}\left(22,45.0,67\right.$, dan $\left.90.0 \mathrm{~kg} \mathrm{~N} \mathrm{ha}^{-1}\right)$. Hal ini diduga bahwa nitrogen yang diberikan belum dapat di respon oleh tanaman yang merupakan varietas lokal. Penelitian ini berbeda dengan penelitian Menza et al. (2017) yang menyebutkan bahwa pemberian nitrogen pada tanaman kedelai meningkatkan $11 \%$ produksi dibanding yang tidak diberikan pupuk nitrogen.

Dugaan produktivitas kacang tunggak pada penelitian ini tidak berbeda secara statistik, berkisar 1.44-1.65 ton ha $^{-1}$ (Tabel 2). Dugaan produktivitas pada penelitian ini lebih tinggi dibandingkan penelitian sebelumnya yaitu berkisar 0.17-0.30 ton ha $^{-1}$ (Liana et al., 2019). Walaupun secara statistik hasil biji tidak dipengaruhi oleh perlakuan pemupukan, akan tetapi ada kecenderungan $(\mathrm{Pr}>\mathrm{F}=0.0887)$ aplikasi pupuk kandang 2.5 ton $\mathrm{ha}^{-1}$ dan $45 \mathrm{~kg} \mathrm{~N}^{-1}$ menghasilkan bobot biji per tanaman dan produktivitas biji

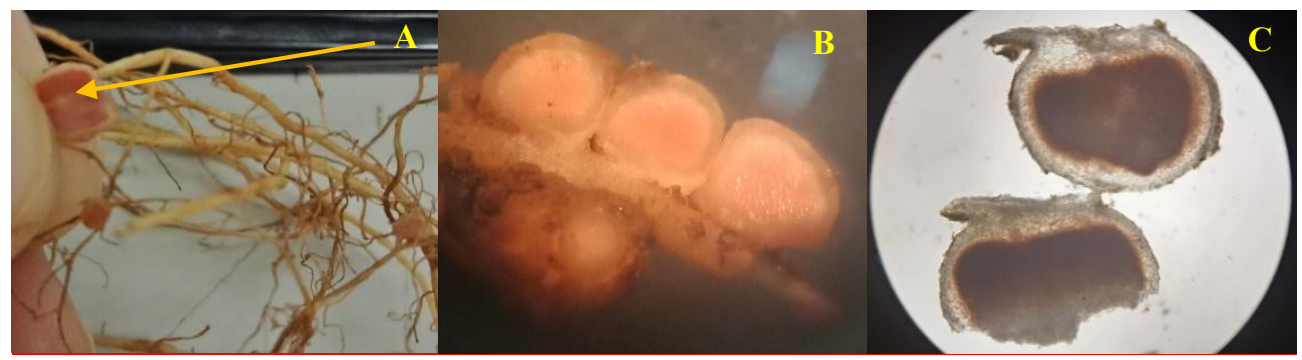

Gambar 3. (A dan B) Penampilan melintang bintil akar kacang tunggak berwarna merah muda, (C) penampilan melintang bintil akar dengan pembesaran 10x pada mikroskop

Tabel 1. Pengaruh pupuk kandang dan pupuk $\mathrm{N}$ terhadap bobot segar daun, bobot kering daun, indeks luas daun, rasio tajuk/ akar, bobot akar, jumlah tandan, dan jumlah bunga pada 5 MST

\begin{tabular}{|c|c|c|c|c|c|c|c|}
\hline Perlakuan & $\begin{array}{c}\text { BSD } \\
(\mathrm{g})\end{array}$ & $\begin{array}{c}\text { BKD } \\
(\mathrm{g})\end{array}$ & ILD & $\begin{array}{c}\text { Rasio } \\
\text { T/A }\end{array}$ & $\begin{array}{c}\text { BKA } \\
(\mathrm{g})\end{array}$ & $\begin{array}{c}\text { Jumlah } \\
\text { tandan per } \\
\text { tanaman }\end{array}$ & $\begin{array}{c}\text { Jumlah } \\
\text { bunga per } \\
\text { tanaman }\end{array}$ \\
\hline \multicolumn{8}{|c|}{ Pupuk kandang (ton ha' ${ }^{-1}$ ) } \\
\hline 0 & $93.63 b$ & 11.10 & 1.39 & 34.25 & 0.75 & $4.6 b$ & 6.6 \\
\hline 2.5 & $89.23 b$ & 10.96 & 1.59 & 25.48 & 1.05 & $7.5 \mathrm{a}$ & 9.0 \\
\hline 5 & $132.32 \mathrm{a}$ & 14.33 & 2.16 & 33.50 & 0.93 & $9.1 \mathrm{a}$ & 12.5 \\
\hline \multicolumn{8}{|c|}{ Pupuk N (kg ha $\left.{ }^{-1}\right)$} \\
\hline 0 & $93.33 b$ & 10.55 & $1.41 \mathrm{~b}$ & $21.41 b$ & $0.99 \mathrm{a}$ & 5.4 & $9.5 \mathrm{ab}$ \\
\hline 15 & $95.40 \mathrm{~b}$ & 11.23 & $1.49 \mathrm{~b}$ & $26.93 b$ & $1.06 \mathrm{a}$ & 6.9 & $5.9 b$ \\
\hline 30 & $90.44 b$ & 12.81 & $1.61 b$ & $29.15 b$ & $0.94 \mathrm{a}$ & 6.7 & $9.1 \mathrm{~b}$ \\
\hline 45 & $141.08 \mathrm{a}$ & 13.93 & $2.33 \mathrm{a}$ & $46.81 \mathrm{a}$ & $0.64 b$ & 9.2 & $13.0 \mathrm{a}$ \\
\hline
\end{tabular}

Keterangan: Angka yang diikuti huruf yang sama pada kolom yang sama tidak berbeda nyata menurut uji BNJ taraf 5\%; BSD = bobot segar daun; $\mathrm{BKD}=$ bobot kering daun; ILD = Indeks Luas daun; Rasio T/A = rasio tajuk/akar; BKA = bobot kering akar 
Tabel 2. Bobot biji per tanaman, bobot 100 biji dan produktivitas kacang tunggak

\begin{tabular}{|c|c|c|c|c|}
\hline Perlakuan & $\begin{array}{l}\text { Bobot biji per } \\
\text { tanaman }(\mathrm{g})\end{array}$ & $\begin{array}{c}\text { Bobot } 100 \text { biji } \\
(\mathrm{g})\end{array}$ & $\begin{array}{c}\text { Hasil biji kadar air } \\
13 \%\left(\mathrm{~g} \mathrm{~m}^{-2}\right)\end{array}$ & $\begin{array}{c}\text { Hasil biji kadar air } \\
13 \%\left(\text { ton } \mathrm{ha}^{-1}\right)^{*}\end{array}$ \\
\hline \multicolumn{5}{|c|}{ Pupuk kandang (ton $\mathrm{ha}^{-1}$ ) } \\
\hline 0 & 28.48 & 14.61 & 142.43 & 1.14 \\
\hline 2.5 & 42.89 & 14.02 & 214.45 & 1.71 \\
\hline 5 & 36.63 & 14.55 & 183.16 & 1.59 \\
\hline \multicolumn{5}{|c|}{ Pupuk N (kg ha $\left.{ }^{-1}\right)$} \\
\hline 0 & 36.12 & 14.52 & 180.61 & 1.44 \\
\hline 15 & 32.81 & 14.50 & 164.65 & 1.31 \\
\hline 30 & 33.73 & 14.20 & 168.65 & 1.34 \\
\hline 45 & 41.34 & 14.34 & 206.72 & 1.65 \\
\hline
\end{tabular}

Keterangan: Angka yang diikuti huruf yang sama pada kolom yang sama tidak berbeda nyata menurut uji BNJ taraf 5\%; bobot biji kering per tanaman dengan kadar air $13 \% .{ }^{*}$ produktivitas dihitung $=\left(\right.$ produktivitas $\left./ \mathrm{m}^{2}\right) /\left(10,000 \mathrm{~m}^{2}\right) \mathrm{x} 80 \%$

Tabel 3. Analisis kandungan nutrisi (proksimat) kacang tunggak*)

\begin{tabular}{|c|c|c|c|c|c|c|}
\hline \multicolumn{2}{|c|}{ Perlakuan } & \multirow{2}{*}{$\begin{array}{l}\mathrm{Abu} \\
(\%)\end{array}$} & \multirow{2}{*}{$\begin{array}{l}\text { Protein } \\
(\%)\end{array}$} & \multirow{2}{*}{$\begin{array}{c}\text { Lemak } \\
(\%)\end{array}$} & \multirow{2}{*}{$\begin{array}{c}\text { Serat kasar } \\
(\%)\end{array}$} & \multirow{2}{*}{$\begin{array}{c}\text { Karbohidrat } \\
(\%)\end{array}$} \\
\hline $\begin{array}{l}\text { Dosis pukan } \\
\text { (ton ha-1) }\end{array}$ & $\begin{array}{l}\text { Dosis N } \\
\left(\mathrm{kg} \mathrm{ha}^{-1}\right)\end{array}$ & & & & & \\
\hline 0 & 0 & 4.57 & 23.03 & 2.01 & 3.95 & 52.81 \\
\hline 0 & 15 & 4.73 & 22.05 & 1.53 & 3.95 & 54.01 \\
\hline 0 & 30 & 4.61 & 20.97 & 1.48 & 3.14 & 56.15 \\
\hline 0 & 45 & 4.66 & 22.51 & 1.12 & 2.88 & 55.37 \\
\hline 2.5 & 0 & 4.88 & 21.12 & 1.32 & 3.58 & 56.44 \\
\hline 2.5 & 15 & 4.91 & 22.25 & 1.28 & 3.27 & 54.36 \\
\hline 2.5 & 30 & 4.88 & 21.25 & 1.31 & 3.17 & 55.52 \\
\hline 2.5 & 45 & 4.80 & 21.75 & 1.07 & 3.74 & 54.92 \\
\hline 5 & 0 & 4.75 & 20.56 & 1.40 & 3.33 & 58.25 \\
\hline 5 & 15 & 4.76 & 22.52 & 1.27 & 3.97 & 53.11 \\
\hline 5 & 30 & 4.90 & 20.85 & 0.57 & 3.97 & 57.39 \\
\hline 5 & 45 & 4.77 & 21.36 & 2.44 & 4.09 & 55.62 \\
\hline
\end{tabular}

Keterangan: Pukan= pupuk kandang; N= pupuk starter; *) Hasil analisis produksi laboratorium Pusat Penelitian Sumberdaya Hayati dan Bioteknologi, LPPM IPB (2019); Nilai tidak dianalisis statistik

yang lebih baik daripada tanpa pupuk kandang dan aplikasi pupuk kandang 5 ton ha $^{-1}$.

Hasil analisis proksimat kandungan nutrisi kacang tunggak dari penelitian ini berkisar 20.56-23.03\% protein, karbohidrat $52.81-58.25 \%, 4.57-4.91 \%$ abu, $0.57-2.44 \%$ lemak, dan 2.88-4.09\% serat kasar (Tabel 3). Tabel 3 menunjukan biji dari tanaman yang tidak dipupuk menghasilkan protein dengan kadar yang lebih baik daripada tanaman yang dipupuk, akan tetapi masih perlu dilakukan uji lebih lanjut tentang pengaruh pemupukan pada kualitas biji. Kacang tunggak dipanen masak pada umur 59-81 hari setelah tanam. Umur panen yang relatif singkat dapat menjadi alternatif untuk memproduksi biji kacang tunggak sebagai bahan subtitusi kedelai untuk bahan baku pangan. Wardiah et al. (2016) menyatakan bahwa hasil uji organoleptik yang terdiri dari kualitas warna, aroma, tekstur, rasa tempe kacang tunggak yang menggunakan ragi dari media ubi kayu memberikan kualitas tempe yang disenangi konsumen. Hasil analisis tanah setelah tanam menunjukkan peningkatan $\mathrm{P}$ tersedia dan $\mathrm{pH}$ tanah pada setiap perlakuan (Tabel 4). Affandi et.al. (2015), menyatakan bahwa pemberian pupuk organik dapat meningkatkan $\mathrm{pH}$ tanah, walaupun masih dalam kategori masam, dan kandungan $\mathrm{P}$ tanah, karena adanya pelapukan P-organik.

Hasil uji korelasi peubah jumlah tandan, bobot kering akar, indeks luas daun, bobot segar daun dan bobot biji 
Tabel 4. Analisis tanah pada awal dan akhir penelitian*)

\begin{tabular}{|c|c|c|c|c|c|}
\hline \multicolumn{2}{|c|}{ Perlakuan } & \multicolumn{2}{|c|}{$\mathrm{pH}$ tanah penelitian } & \multicolumn{2}{|c|}{ P-tersedia $\left(\mathrm{ppm} \mathrm{P}_{2} \mathrm{O}_{5}\right)$} \\
\hline Dosis pukan (ton ha' $\left.{ }^{-1}\right)$ & Dosis N $\left(\mathrm{kg} \mathrm{ha}^{-1}\right)$ & awal & akhir & awal & akhir \\
\hline 0 & 0 & 4.15 & 4.57 & 1.81 & 23.03 \\
\hline 0 & 15 & 4.15 & 4.73 & 1.81 & 22.05 \\
\hline 0 & 30 & 4.15 & 4.61 & 1.81 & 20.97 \\
\hline 0 & 45 & 4.15 & 4.66 & 1.81 & 22.51 \\
\hline 2.5 & 0 & 4.15 & 4.88 & 1.81 & 21.12 \\
\hline 2.5 & 15 & 4.15 & 4.91 & 1.81 & 22.25 \\
\hline 2.5 & 30 & 4.15 & 4.88 & 1.81 & 21.25 \\
\hline 2.5 & 45 & 4.15 & 4.8 & 1.81 & 21.75 \\
\hline 5 & 0 & 4.15 & 4.75 & 1.81 & 20.56 \\
\hline 5 & 15 & 4.15 & 4.76 & 1.81 & 22.52 \\
\hline 5 & 30 & 4.15 & 4.90 & 1.81 & 20.85 \\
\hline 5 & 45 & 4.15 & 4.77 & 1.81 & 21.36 \\
\hline
\end{tabular}

Keterangan: *Hasil uji di Laboratorium Pengujian Departemen Agronomi dan Hortikultura IPB (2019) Nilai tidak dianalisis statistik

Tabel 5. Korelasi antar peubah vegetatif dan generatif tanaman kacang tunggak

\begin{tabular}{|c|c|c|c|c|c|c|}
\hline $\begin{array}{l}\text { Peubah } \\
\text { Pengamatan }\end{array}$ & Jumlah tandan & $\begin{array}{l}\text { Bobot kering } \\
\text { akar }\end{array}$ & $\begin{array}{c}\text { Indeks luas } \\
\text { daun }\end{array}$ & $\begin{array}{c}\text { Bobot segar } \\
\text { daun }\end{array}$ & $\begin{array}{c}\text { Bobot kering } \\
\text { daun }\end{array}$ & $\begin{array}{l}\text { Bobot biji } \\
\text { kering per } \\
\text { tanaman }\end{array}$ \\
\hline Jumlah bunga & $0.6249 * *$ & $0.7765^{*}$ & $0.4733 * *$ & $0.6587 * *$ & $0.4933 * *$ & $0.7688^{*}$ \\
\hline Jumlah tandan & & $-0.1428 \mathrm{tn}$ & $0.5575^{* *}$ & $0.3940^{*}$ & $0.3029 \mathrm{tn}$ & $-0.7425 \mathrm{tn}$ \\
\hline Bobot kering akar & & & $-0.2415 \mathrm{tn}$ & $-0.7456 \mathrm{tn}$ & $-0.3483 \mathrm{tn}$ & $-0.6524 \mathrm{tn}$ \\
\hline Indeks luas daun & & & & $0.6972 * *$ & $0.5175^{* *}$ & $-0.5941 \mathrm{tn}$ \\
\hline Bobot segar daun & & & & & $0.5749 * *$ & $-0.9026^{*}$ \\
\hline Bobot kering daun & & & & & & $-0.9582 *$ \\
\hline
\end{tabular}

Keterangan: tn: tidak berbeda nyata; *: nyata taraf 5\%;**: nyata taraf $1 \%$

kering per tanaman terlihat pada Tabel 5. Hasil uji korelasi menunjukkan bahwa peubah yang memiliki korelasi positif dengan bobot biji kadar air 13\% per tanaman yaitu jumlah bunga per tanaman dengan nila $\mathrm{r}=0.7688$, artinya semakin banyak jumlah bunga maka semakin tinggi bobot biji yang dihasilkan per tanaman. Hasil penelitian pada 20 varietas tanaman kedelai menunjukkan bahwa jumlah bunga berkolerasi dengan jumlah polong isi yang dihasilkan per tanaman (Suyamto dan Musalamah, 2010). Jumlah polong berkolerasi dengan bobot biji per tanaman (Sa'diyah et al., 2015). Hasil uji korelasi bobot biji kadar air 13\% per tanaman memiliki korelasi negatif dengan bobot segar daun dan bobot kering daun. Selain itu bobot biji kadar air 13\% per tanaman berkolerasi negatif dengan jumlah tandan, bobot kering akar dan indeks luas daun, namun pengaruhnya tidak nyata. Penelitian ini sejalan dengan penelitian Krisnawati dan Adie (2016), menyatakan fase vegetatif kedelai yaitu tinggi, jumlah buku, jumlah cabang, berkolerasi negatif dengan hasil biji kedelai.

\section{KESIMPULAN}

Pemberian pupuk kandang meningkatkan bobot segar daun, jumlah tandan bunga, jumlah bunga, bobot akar pada 5 MST. Pemberian pupuk $\mathrm{N}$ meningkatkan bobot segar daun, indeks luas daun, dan bobot akar pada 5 MST. Kombinasi pemberian pupuk organik dengan dosis 2.5 ton ha-1 diikuti pupuk nitrogen $45 \mathrm{~kg} \mathrm{ha}^{-1}$ memberikan pertumbuhan dan produksi yang cenderung lebih baik daripada tanpa pemupukan. Dengan demikian kacang tunggak dapat diproduksi dengan input pupuk kandang dan $\mathrm{N}$ dosis rendah.

\section{DAFTAR PUSTAKA}

Abbadi, J., J. Gerendás, B. Sattelmacher. 2008. Effects of nitrogen supply on growth, yield and yield components of safflower and sunflower. Plant Soil. 306(1):167-18. DOI: 10.1007/s11104-008-9569-5. 
Atmaja, T., M.M.B. Damanik, Mukhlis. 2017. Pengaruh pemberian pupuk kandang ayam, pupuk hijau, dan kapur $\mathrm{CaCO}_{3}$ pada tanah ultisol terhadap pertumbuhan tanaman jagung. J. Agroekoteknol. FP USU. 5:208215.

Afandi, F.N., B. Siswanto, Y. Nuraini. 2015. Pengaruh pemberian berbagai jenis bahan organik terhadap sifat kimia tanah pada pertumbuhan dan produksi tanaman ubi jalar di Entisol Ngrangkah Pawon, Kediri. J. Tanah Sumberdaya Lahan. 2:237-244.

Animasaun, D.A., S.Y.K. Oyedeji, O.T. Azeez, Mustapha, M.A. Azeez. 2015. Genetic variability study among ten cultivars of cowpea (Vigna unguiculata L. Walp) using morpho-agronomic traits and nutritional composition. J. Agric. Sci. 10:119-130.

Boroomandan, P., M. Khoramivafa, Y. Haghi, A. Ebrahimi. 2009. The effects of nitrogen starter fertilizer and plant density on yield, yield components and oil and protein content of soybean (Glycine max L. Merr). Pak. J. Biol. Sci. 12:378-382.

Carvalho, A.F.U., N.M.D. Sousa, D.F. Farias, C.B.D.R Bezerra, R.M.P.D. Silva, M.P. Viana, S.T. Gouveia, S.S. Sampaio, M.B.D. Sousa, G.P.G. Lima, S.M.D. Morais, C.C. Barros. 2012. Nutritional ranking of 30 Brazilian genotypes of cowpeas including determination of antioxidant capacity and vitamins. J. Food Composit Anal. 26:81-88.

Dewi, I.W.R., C. Anam, E. Widowati. 2014. Karakteristik sensoris, nilai gizi dan aktivitas antioksidan tempe kacang gude (Cajanus cajan) dan tempe kacang tunggak (Vigna unguiculata) dengan berbagai variasi waktu fermentasi. Biofarmasi.12:73-82.

Dinariani, Y.B., S. Heddy, B. Guritno. 2014. Kajian penambahan pupuk kandang kambing dan kerapatan tanaman yang berbeda pada pertumbuhan dan hasil tanaman jagung manis (Zea mays saccharata Sturt). J. Produksi Tan. 2:128-136.

Enyiukwu, D.N., A.C. Amadioha, C.C. Ononuju. 2018. Nutritional significance of cowpea leaves for human consumption. Greener Trends Food Sci. Nutr. 1:110 .

Hayati, E. 2010. Pengaruh pupuk organik dan anorganik terhadap kandungan logam berat dalam tanah dan jaringan tanaman selada. J. Floratek. 5:113-123.

Hindersah, R., N. Rostini, A. Harsono, Nuryani. 2017. Peningkatan populasi, pertumbuhan dan serapan nitrogen tanaman kedelai dengan pemberian azotobacter penghasil eksopolisakarida. J. Agron. Indonesia 45:30-35.
Huang, W., D.A. Ratkowsky, C. Hui, P. Wang, J. Su, P. Shi. 2019. Leaf fresh weight versus dry weight: Which is better for describing the scaling relationship between leaf biomass and leaf area for broad-leaved plants? J. Forest. 10:1-19.

Horvath, M.K., Z. Polgar, N.R. Arany, I. Cernak, J. Taller, B. Hoffiman. 2014. The effect of nitrogen supply on leaf area index, leaf chlorophyll and tuber nitrogen content in potato. J. Georgikon Agric. 18:49-59.

Krisnawati, A., dan M.M. Adie. 2016. Hubungan antar komponen morfologi dengan karakter hasil biji kedelai. Bul. Palawija 14:49-54.

Kritzinger, Q., N. Lall, T.A.S. Aveling. 2015. Antimicrobial activity of cowpea (Vigna unguiculata) leaf extracts. South African J. Bot. 71:45-48.

Liana, D., H. Purnamawati, M. Melati, Y. Wahyu. 2019. Determination of the optimum rate of $\mathrm{N}$ fertilizers with addition of goat manure for production of cowpea (Vigna unguiculata [L.] Walp). J. Trop Crop Sci. 6:121-128.

Liferdi, L. 2010. Efek pemberian fosfor terhadap pertumbuhan dan status hara bibit manggis. J. Hort. 20:18-26.

Menzaa, N.C.L., J.P. Monzon, J.E. Spech, P. Grassini. 2017. Is soybean yield limited by nitrogen supply? Field Crops Res. 213:204-212.

Murtini, E.S., N.O.S. Lestari. 2017. Formulasi cookies sumber protein berbahan tepung kacang tunggak sebagai upaya pemanfaatan komoditas lokal. J. PATPI. 28:194-200.

Mukhtar A.A., E.C. Odion, A. Ahmed, B. Babaji, A. Aminu, A.M. Mukhtar, U.L. Arunah. 2014. Comparative effects of organic manure sources and rates on performance of groundnut varieties. In G. Rahmann and U. Aksoy (Eds.). Proceedings of the $4^{\text {th }}$ ISOFAR Scientific Conference. Istanbul. Turkey 13-15 October 2014.

Prajapati, K., H.A. Modi. 2012. The importance of potassium in plant growth - A review. Indian J. Plant Sci. 1:177-186.

Purnamawati, H., R. Poerwanto, I. Lubis, Yudiwanti, S.A.Rais, A.G.Manshuri. 2010. Akumulasi dan distribusi bahan kering pada beberapa kultivar kacang tanah. J. Agron. Indonesia 38:100-106. 
Ramli, A.K. Paloloan, Rajamuddin. 2016. Perubahan sifat fisik tanah akibat pemberian pupuk kandang dan mulsa pada pertanaman terung ungu (Solanum melongena L.), entisol, Tondo Palu. e-J. Agrotekbis. 4:160-167.

Rastiyanto, E.A., Sutirman, A. Pullaila. 2013. Pengaruh pemberian pupuk organik kotoran kambing terhadap pertumbuhan dan hasil tanaman kailan (Brassica oleraceae. L). Bul. IKATAN. 3:2.

Sa'diyah, N., C.R. Siagian, M. Barmawi. 2015. Korelasi dan analisis lintas karakter agronomi kedelai (Glycine $\max$ [L.] Merrill) keturunan persilangan Wilis $\mathrm{X}$ MLG 2521. J. Penel. Pert. 16:45-53.

Setyowati, M., Sutoro. 2010. Evaluasi plasma nutfah kacang tunggak (Vigna unguiculata L.) di lahan masam. Bul. Plasma Nutfah. 16:45-48.

Siregar, H.M., J. Jamilah, H. Hanum. 2015. Aplikasi pupuk kandang dan pupuk SP-36 untuk meningkatkan unsur hara $\mathrm{P}$ dan pertumbuhan tanaman jagung (Zea mays L.) di tanah inceptisol Kwala Bekala. J. Agroekoteknologi. 3:710-716.
Suryantini. 2015. Pembintilan dan penambatan nitrogen pada tanaman kacang tanah. Balai Penelitian Tanaman Aneka Kacang dan Umbi. Monograf Balitkabi. 13:234-247.

Suyamto dan Musalamah. 2010. Kemampuan berbunga, tingkat keguguran bunga, dan potensi hasil beberapa varietas kedelai. Bul. Plasma Nutfah. 16:38-43.

Thomas, T.C., A.C. Thomas. 2009. Vital role of potassium in the osmotic mechanism of stomata aperture modulation and its link with potassium deficiency. Plant Signal Behav. 4:240-243.

Uwah, D.F., V.E. Eyo. 2014. Effects of number and rate of goat manure application on soil properties, growth and yield of sweet maize (Zea mays L. saccharata Strut). Sust. Agricul Res. 3:75-83.

Wardiah, Samingan, A. Putri. 2016. Uji preferensi tempe kacang tunggak (Vigna unguiculata (L.) Walp.) yang difermentasi dengan berbagai jenis ragi. J. Agroindustri. 6:34-41.

Zakariyya, F. 2016. Menimbang indeks luas daun sebagai variabel penting pertumbuhan tanaman kakao. Warta Pusat Penel. Kopi Kakao Indonesia. 28:8-12. 